\title{
ANALYSING LEARNING AT THE INTERFACE OF SCIENTIFIC AND TRADITIONAL ECOLOGICAL KNOWLEDGE IN A MANGROVE ECOSYSTEM RESTORATION SCENARIO IN THE EASTERN COAST OF TANZANIA
}

\author{
Daniel SABAI* and Heila SISITKA ** \\ * Environmental Learning Research Centre (ELRC), Rhodes University, South Africa, \\ dsabainew@hotmail.com \\ ** Environmental Learning Research Centre (ELRC), Rhodes University, South Africa, elrc@ru.ac.za
}

DOI: $10.2478 /$ trser-2013-0027

KEYWORDS: community-based participatory monitoring, mangrove ecosystem, scientific indicators, context-based learning, scientific knowledge, traditional ecological knowledge, traditional ecological indicators, under-labouring.

\section{ABSTRACT}

Records from community-based coastal management initiatives indicate that local communities who are key actors in activities that aim at safeguarding the health status of terrestrial and marine ecosystems face a lot of challenges associated with adapting and applying indicators that are scientifically abstracted and methodologically too reified, given varying social, contextual and technical conditions prevailing amongst them.

This paper brings into view possible challenges of adapting and applying scientific indicators in community-based monitoring of mangrove ecosystem and suggests a new approach that may lead to development of indicators which are less reified, more congruent to users (coastal communities) and likely to attract a wider social learning in the mangrove restoration context. It also sets a bridge for scientific institutions (including universities), to understand various social, cultural and contextual needs that determine epistemological access between them and local communities, which need to be addressed prior to engaging target communities in participatory monitoring programmes.

The paper attempts to analyse learning at the interface of knowledge that scientific institutions produce and the potential knowledge that exists in local context (traditional ecological knowledge) for purposes of widening and improving knowledge sharing and safeguarding the health status of mangrove species and fisheries that use them as key habitats.

The paper stems from a study which employs processes of abstraction and experiential learning techniques such as Experiential Learning Intervention Workshop carried out in 2012, to unlock knowledge that local communities have, as an input for underlabouring existing scientific indicators in the eastern coast of Tanzania.

It brings into view the need to consider contextual realities on ground, the level of education that the participating group has, the minimum level of participation that is required, structures that govern coastal monitoring practices at local level and the need for scientific institutions to consider the knowledge that local people have as an input for enhancing or improving coastal monitoring, especially monitoring of mangrove and fishery resources.

The paper finally comes up with a framework of indicators which is regarded by coastal communities as being less reified, more contextually and culturally congruent and which can easily be used in detecting environmental trends, threats, changes and conditions of mangrove and fisheries resources, and attract wider social learning processes. 
ZUSAMMENFASSUNG: Analyse des Lernens an der Schnittstelle wissenschaftlicher und traditioneller ökologischer Kenntnisse in einem Mangroven-Ökosystem Renaturierungs-Szenarium an der Ostküste von Tanzania.

Unterlagen gemeinschaftsgestützter Initiativen von Küstenmanagement zeigen, dass die lokalen Gemeinschaften, die Schlüsselstelle in der beabsichtigten Sicherung des Gesundheitszustandes der terrestrischen und marinen Ökosysteme einnehmen, vor einer Reihe von Herausforderungen stehen, die verbunden sind mit der Anpassung und Umsetzung von Indikatoren, die wissenschaftlich abstrakt und methodisch zu reifiziert sind angesichts der sozialen, kontextabhängigen und technischen Bedingungen, die zwischen ihnen vorherrschen.

Die vorliegende Arbeit veranschaulicht mögliche Herausforderungen zur Anpassung und Anwendung wissenschaftlicher Indikatoren in einem gemeinschaftlich angelegten Monitoring von Mangroven Ökosystemen und regt eine neue Herangehensweise an die Entwicklung von Indikatoren an, die weniger reifiziert sind und mehr den Nutzern (die Küstengemeinden) enstprechen, wodurch sie wahrscheinlich ein weiteres soziales Lernen im Kontext der Renaturierung der Mangroven aktivieren werden. Ebenso legt es eine Brücke zu wissenschaftlichen Institutionen (einschließlich Universitäten), verschiedene soziale, kulturelle und kontextabhängige Notwendigkeiten zu verstehen, die den epistemologischen Zugang zwischen ihnen und den lokalen Gemeinschaften bestimmen, und angesprochen werden müssen, bevor die Zielgemeinden an dem participativen Monitoringprogramm beteiligt werden.

Die Arbeit macht den Versuch, das Lernen an der Schnittstelle der Erkenntnis dessen $\mathrm{zu}$ analysieren, was die wissenschaftlichen Institutionen erarbeiten und dem potentiellen Wissen, das im lokalen Kontext existiert (traditionelles ökologisches Wissen), in der Absicht die gemeinsame Nutzung des vorhandenen Wissens zu erweitern und zu verbessern sowie den Gesundheitszustand der Arten und der Fischereiwirtschaft zu sichern, die Magroven als Schlüsselhabitate nutzen.

Die Arbeit rührt von einer Studie her, die sich mit Abstraktionprozessen und Techniken des Lernens aus Erfahrung, wie Experiential Learning Intervention Workshop (ELIW)/Workshop zur Vermittlung von erfahrungsgemäßem Lernen, beschäftigt, um das in den lokalen Gemeinschaften vorhandene Wissen als einen Beitrag zu den unter Arbeitsbedigungen existierenden wissenschaftlichen Indikatoren an der Ostküste von Tanzania zu erschließen.

Es veranschaulicht die Notwendigkeit, die Tatsachen an der Basis im Kontext zu sehen und zwar den Stand der Bildung, den die teilnehmende Gruppe hat, den minimalen Stand der erforderlichen Teilnahme, die Struktur, die Monitoring Praktiken auf lokaler Ebene beherrscht sowie die Notwendigkeit für wissenschaftliche Institutionen die vorhandenen Kenntnisse der lokalen Bevölkerung in Betracht zu ziehen als einen Beitrag zur Leistungsförderung oder zur Verbesserung des Küstenmonitorings, insbesondere das Monitoring der Mangroven und der Fischereiressourcen.

Schließlich bringt die Arbeit ein Bezugssystem von Indikatoren zur Sprache, das bei den Küstengemeinschaften als weniger reifiziert und mehr kontextabhängig sowie kulturell entsprechend ist. $\mathrm{Zu}$ dem kann es leicht angewendet werden bei der Erkennung von Umwelttrends, Gefahren, Veränderungen, Zustand der Mangroven und Fischereiressourcen, und findet Beachtung bei weiteren sozialen Lernprozessen. 
REZUMAT: Analiza învăţării la limita dintre cunoştinţele ştiinţifice şi cele ecologice tradiţionale, în scenariul restaurării unui ecosistem de mangrove de pe coasta estică a Tanzaniei.

Informații/mărturii ale iniţiativelor de management de coastă, bazate pe comunitate indică faptul că personajele-cheie ale activităţilor care au ca scop protejarea stării de sănătate a ecosistemelor terestre şi marine - comunităţile locale, se confruntă cu o mulţime de provocări legate de adaptarea şi aplicarea indicatorilor, care sunt din punct de vedere ştiinţific şi metodologic prea abstracţi, având în vedere condiţiile sociale, contextuale şi tehnice existente.

Această lucrare aduce în atenţie posibile provocări de adaptare şi punere în practică a indicatorilor în monitorizarea ecosistemelor de mangrove, bazată pe comunitate şi sugerează o nouă abordare care ar putea duce la dezvoltarea indicatorilor, care sunt mai puţin abstracţi, mai apropiaţi de utilizatori (comunităţile de coastă) şi de natură, să atragă o învăţare socială mai largă în contextul restaurării mangrovelor. De asemenea, aceasta stabileşte o punte de legătură între instituţiile ştiinţifice (inclusiv universităţi), pentru o mai bună înţelegere a diverselor nevoi sociale, culturale şi contextuale, care determină accesul epistemologic între acestea şi comunităţile locale, care trebuie să fie abordate înainte de a introduce comunităţile ţintă în participarea în cadrul programelor de monitorizare.

Lucrarea reprezintă o încercare de analiză a învăţării la interfaţa cunoştinţelor pe care instituţiile ştiinţifice le produc şi potenţialul de cunoaştere, care există în contextul local (cunoştinţe ecologice tradiţionale) în scopul lărgirii şi îmbunătăţirii schimbului de cunoştinţe şi protejarea stării de sănătate a speciilor de mangrove şi a pescăriilor care le folosesc ca habitate cheie.

Lucrarea provine dintr-un studiu care utilizează procese de abstractizare şi tehnici de învăţare din experienţă, cum ar fi Experiential Learning Intervention Workshop (ELIW) pentru a debloca cunoştinţele pe care comunităţile locale le au, ca un impuls pentru indicatorii ştiinţifici mai puţin eficienţi existenţi pe coasta de est a Tanzaniei.

Studiul aduce în prim plan necesitatea de a lua în considerare realitatea din teren, nivelul de educaţie al grupului participant, nivelul minim de participare care este necesar, structura care guvernează practicile de monitorizare de coastă la nivel local şi necesitatea ca instituţiile ştiinţifice să ia în considerare cunoştinţele pe care localnicii le au ca şi un plus pentru consolidarea sau îmbunătăţirea monitorizării de coastă, mai ales a monitorizării mangrovelor şi a resurselor piscicole.

Lucrarea vine, în cele din urmă, cu un model de indicatori care este considerat de către comunităţile costiere ca fiind mai puţin abstract, mai contextual şi congruent cultural, indicatori care pot fi folosiţi cu uşurinţă în detectarea tendinţelor de mediu, a ameninţărilor, schimbărilor şi care condiţionează mangrovele şi resursele piscicole şi atrag procese sociale mai ample de învăţare.

\section{INTRODUCTION}

Learning occurs through conscious and unconscious processes (Breen, 2013) and is not detached from day to day human practices (Lotz-Sisitka, 2012). Much lies in the kind of knowledge that is adapted or generated in various settings as a solution for emerging social, economic, and environmental challenges in the social world.

Debates regarding how people learn can be dated back to the era of Greek philosophers (Socrates-469-399 B.C., Plato 427-347 B.C., and Aristotle 384-322 B.C.) and have since then been filtered to reflect not only philosophical, psychological and biological 
views but also different dimensions and contexts such as social, cultural, economic, and ecological (Hammond et al., 2001; Reed et al., 2006; Mostert et al., 2007; Pahl-Wostl et al., 2007; Muro and Jeffrey, 2008).

The past two decades have witnessed an increase in global, regional, and local efforts emphasizing the need to create and raise awareness among users of natural resources (particularly mangroves, fisheries, seas grasses, and coral-reefs in different parts of the world). This awareness is especially necessary for those at the grassroots level in low income countries because they may become involved in the periodic detection of environmental trends, threats, conditions, and changes of coastal and marine resources (commonly known as periodicmonitoring); and thus exposing them to "learning by doing"; an approach which encourages learning by taking part in the practice (NEECS, 2005-2009).

Some of the key reasons that underpin the justification for this form of communitybased learning are that coastal areas contain diverse and productive habitats necessary for sustenance and subsistence of the world's poor who live around them. It is also recognised that coastal resources are vital for many local communities and indigenous people (UNCED, 1992; NICEMS, 2003). Such participatory monitoring practices are thus carried out to safeguard the health status of the coastal environment, due to increasing pressures from the demand for coastal resources by surrounding local communities (Wagner, 2005; NICEMS, 2003) and the need to support involved communities in order to understand both the value of ecological systems that surround them and assume a leading role in protecting them.

Lotz-Sisitka (2012) argues that learning which takes place in community-based natural resource management contexts encourages knowledge sharing, experimentation, reflective practice, problem solving, effective monitoring and informed planning, leading to behavioural change and trust. Leys and Vanclay (2010) view such forms of learning as an approach that can strengthen communities' capacity to collectively manage ecosystems sustainably.

While learning through direct involvement in practice is necessary (Kuper et al., 2009), much lies on the methods and the indicators employed by development experts and scientists in participatory natural resource management initiatives such as monitoring of mangroves resources and fisheries. In East Africa, (particularly Tanzania where Integrated Coastal Management Programmes were initiated in early, mid and late 1990s under internal and external funding) specific monitoring plans were developed by scientific institutions to guide community-based monitoring practices (KICAMP, 2005). The said monitoring plans contained scientific indicators and methodologies adapted from the Survey Manual for Tropical Marine Resources (English et al., 1994) and were believed to be "in line with those put forward by the Science and Technical Working Group (STWG) of Tanzania Coastal Management Partnership” (KICAMP, 2005).

After several years of implementing community-based monitoring plans, it was observed that local participants (coastal communities) struggled to "understand and apply" the scientific framework of indicators (KICAMP, 2004). This observation was affirmed in 2005, when one of the studies carried out along the eastern Coast of Tanzania indicated that there was no effective monitoring of coastal and marine resources in the area. It thus implies that "learning by doing" did not successfully play out as previously envisaged.

Campbell (2000) affirms that problems are likely to emerge when facilitating firms and organisations prioritize natural scientific norms and approaches in community-based initiatives. Proceedings from the scientific forum on Integrated Coastal Management issues in Tanzania indicate that scientific knowledge was being "presented in a manner that was too complicated" and a form that tended to limit understanding and access to information for management purposes (TCMP, 1998). 
However, this paper does not suggest that the adaption and application of scientific indicators and methodologies in the local context constrain the learning process. It rather raises a concern whether or not conditions that necessitate creation or adaption of scientific knowledge are properly addressed by development experts and scientists prior to involving or engaging target communities in the participatory monitoring of coastal and marine resources, particularly the mangroves and fisheries that use them as key habitats. This paper seeks to communicate to different players who are involved in coastal-based monitoring practices; that effective learning in community-based initiatives may not occur by simply adapting models, plans, and frameworks from other contexts, but by addressing key conditions that are necessary for stimulating and mobilising learning process. These are presented in this paper as key findings and described further using theoretical insights.

A coastal strip that extends from Moa to Boma localities in Mkinga District (Figs. 1 and 2) was picked as the main study site on grounds that it would provide opportunities for selected research participants to work on the environment that they are familiar with, rather than being moved to one specific location. Selection of the site was based on the following criteria:

1) It contained over one thousand hectares of mangrove species with varying ecological characteristics (good for experiential learning);

2) Resource users in the study area had been involved in coastal monitoring practices from the early 1990s and were thus well versed with challenges that are associated with adapting and applying the framework of scientific indicators;

3) The researchers had participated in various community based natural resource management in the study area for over two years and in other coastal sites for over ten years, and therefore, potentially had access to useful information for the intended study.

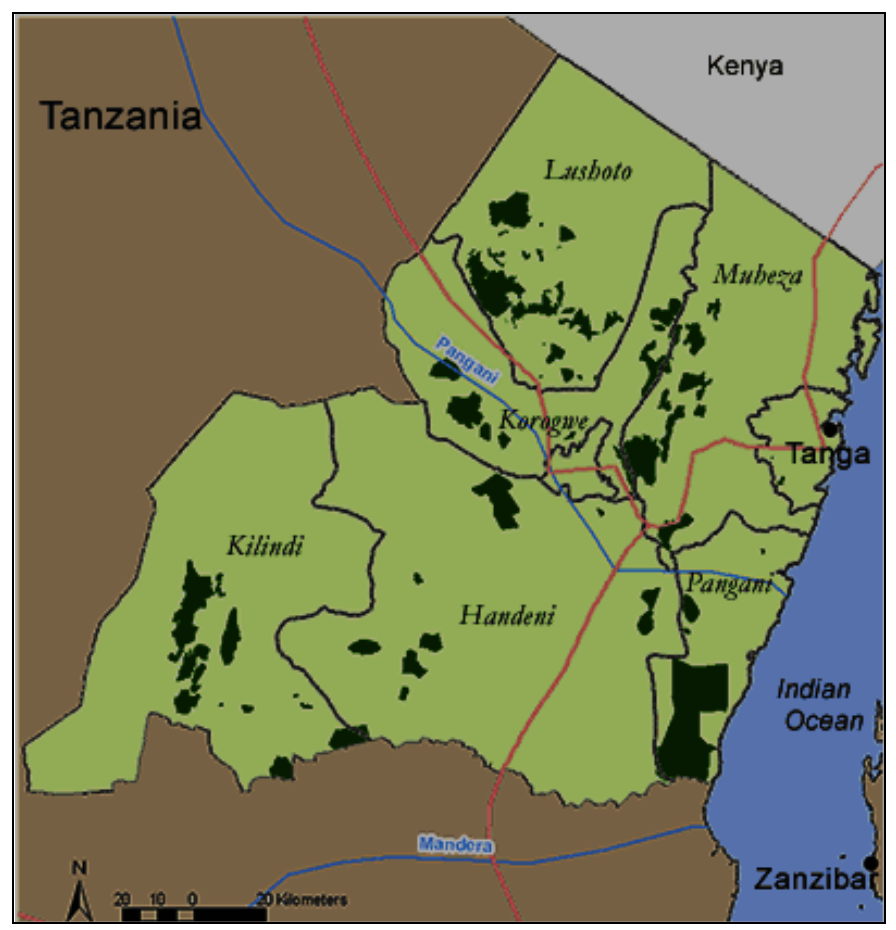

Figure 1: The study area. 


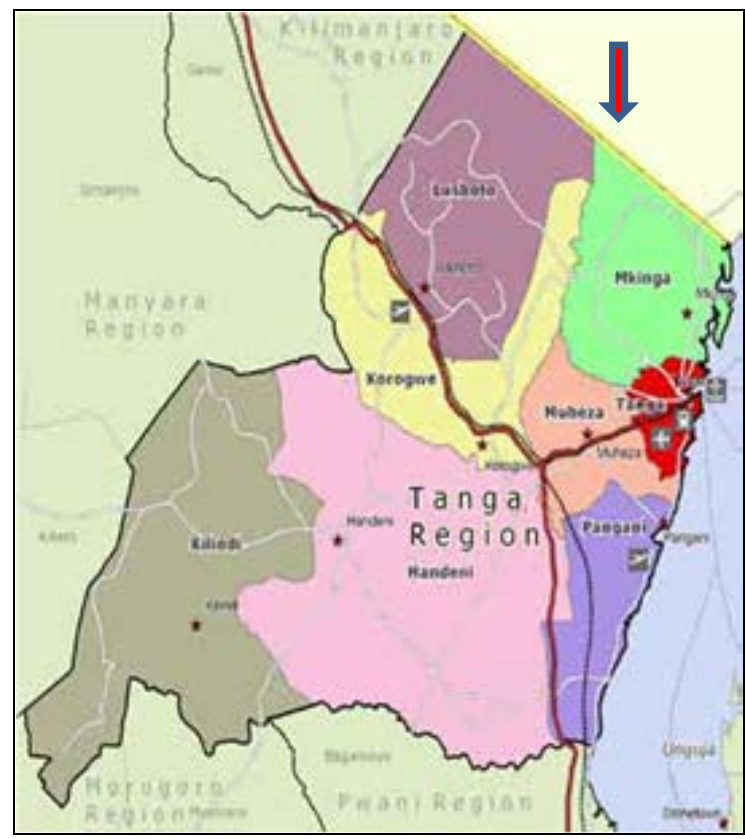

Figure 2: Mkinga District.

\section{MATERIAL AND METHODS}

The study was carried out in a mangrove ecosystem restoration context in the eastern coast of Tanzania to "analyse" possible challenges that enable or constrain learning in participatory monitoring of coastal and marine resources. The study also sought to "examine" existing local knowledge as an input for underlaboring (supporting) the existing scientific framework of indicators in response to the challenges raised by research participants (coastal communities) and the advice given by some scientists that "local input" is required when developing participatory monitoring indicators in order to "accurately measure what is locally important” (Fraser et al., 2005).

It pursued a case study strategy to allow the investigator to "retain holistic and meaningful characteristics of real-life events" (Yin, 2003) that occurs in the mangrove ecosystem. Opting for this strategy also implied choosing to have a deeper understanding of phenomena under study (depth) than how wide they are (breadth). Case study research yields either "descriptive" or "explanatory" knowledge (Babbie, 2001, 2007).

The sampling process (in this study) was guided by Verschuren and Doorewaard (1999) who recommend the use of a "strategic" sample to allow in-depth analysis of the phenomenon under study. Selection of research participants was based on their previous involvement in mangrove and fisheries practice in the study area. Using this criterion, the study selected fishers who had participated in fishing activities for at least 15 years, mangrove restorers with at least ten years record and local elders who had witnessed trends, threats, changes and conditions of fisheries and mangrove resources for at least 20 years. Using previous contacts, the researcher formed a team of five experienced mangrove restorers and fishers (three women and two men) to assist in the process of selecting potential research participants in the study area. The team identified eight elders, six fishers and 12 mangrove restorers whom they believed to have sufficient knowledge of the mangrove ecosystem as per specified sampling criteria. 
Analysis of challenges that emerge from the scientific framework of indicators which enable or constrain learning in participatory monitoring of mangroves and fisheries

The analysis of challenges that enable or constrain learning in participatory monitoring of coastal and marine resources was done through Experiential Learning Intervention Workshop (ELIW) which allowed mangrove restorers, mangrove-based fishers, local elders and marine scientists to mirror the scientific framework of indicators and specifically analyse challenges that are associated with the adaption and application of the same.

\section{Procedures adapted in the ELIW}

The intervention workshop was divided into four main sessions. The first session focused on analysing the level of familiarity and comprehension of attributes that constitute the framework of scientific indicators for monitoring mangrove species and mangrove-based fisheries respectively. The second session focused on identifying and associating scientific monitoring methods and techniques to the attributes or indicators identified during the first session. The third session aimed at examining the capacity of the participants to apply the framework. This session focused on capturing challenges that users of the framework experienced in the process of applying the scientific framework of indicators in the field and recording of the same in special sheets. The first two sessions were introduced to pave the way for the participants to recall various monitoring moments they had gone through, and be able to mirror different challenges that either enabled or constrained them from acquiring knowledge as they took part in the practice. The fourth and last session aimed to analyse the relevance of the indicators to the local context, identify emerging errors, correct observed errors, add local input to improve the framework and produce a user friendly framework (which is contextually relevant and cultural friendly), test the new framework, and provide feedback of the testing exercise. (Tabs. 1-4; Box 1)

Table 1: Level of familiarity and comprehension.

\begin{tabular}{|c|l|c|c|c|l|}
\hline Crt. & \multicolumn{1}{|c|}{$\begin{array}{c}\text { Checklist } \\
\text { enquiry }\end{array}$} & $\begin{array}{c}\text { Responses } \\
\text { given }\end{array}$ & $\begin{array}{c}\text { Total } \\
\text { participants }\end{array}$ & Percentage & $\begin{array}{c}\text { Reason(s) } \\
\text { For "Yes" or "No" }\end{array}$ \\
\hline 1. & $\begin{array}{l}\text { I understand the } \\
\text { components of } \\
\text { the framework }\end{array}$ & 2 & 20 & 10 & $\begin{array}{l}\text { My little formal } \\
\text { knowledge was } \\
\text { enough to help me, } \\
\text { I have been part of } \\
\text { different training } \\
\text { workshops. }\end{array}$ \\
\hline 2. & $\begin{array}{l}\text { I partially } \\
\text { understand the } \\
\text { components of } \\
\text { the framework }\end{array}$ & 5 & 20 & 25 & $\begin{array}{l}\text { I can catch-up with } \\
\text { some components. }\end{array}$ \\
\hline 3. & $\begin{array}{l}\text { I don't understand } \\
\text { the components } \\
\text { of the framework }\end{array}$ & 13 & 20 & 65 & $\begin{array}{l}\text { Used language is } \\
\text { difficult, too many } \\
\text { components, I have no } \\
\text { formal knowledge, I } \\
\text { don't know how to } \\
\text { read and write, I don't } \\
\text { know why I can't } \\
\text { understand them. }\end{array}$ \\
\hline
\end{tabular}


Table 2: Applying the framework of scientific indicators for monitoring mangroves.

\begin{tabular}{|c|l|c|c|c|l|}
\hline Crt. & \multicolumn{1}{|c|}{$\begin{array}{c}\text { Checklist } \\
\text { enquiry }\end{array}$} & $\begin{array}{c}\text { Responses } \\
\text { given }\end{array}$ & $\begin{array}{c}\text { Total } \\
\text { participants }\end{array}$ & Percentage & $\begin{array}{c}\text { Reason(s) } \\
\text { For "Yes" or "No" }\end{array}$ \\
\hline 1. & $\begin{array}{l}\text { I am able to } \\
\text { apply the } \\
\text { framework }\end{array}$ & 2 & 20 & 10 & $\begin{array}{l}\text { Too difficult to } \\
\text { understand, I have no } \\
\text { formal knowledge, not } \\
\text { able to read and write, } \\
\text { I don't know. }\end{array}$ \\
\hline 2. & $\begin{array}{l}\text { I can partially } \\
\text { apply the } \\
\text { framework }\end{array}$ & 8 & 20 & 40 & $\begin{array}{l}\text { We don't use them on } \\
\text { regular basis, they are } \\
\text { difficult, they are too } \\
\text { systematic }\end{array}$ \\
\hline 3. & $\begin{array}{l}\text { I am not able to } \\
\text { apply the } \\
\text { framework }\end{array}$ & 10 & 20 & 50 & $\begin{array}{l}\text { We did not develop } \\
\text { them, they contain } \\
\text { mathematics, and they } \\
\text { are difficult. }\end{array}$ \\
\hline
\end{tabular}

Table 3: Applying the framework of scientific indicators for fisheries.

\begin{tabular}{|c|l|c|c|c|l|}
\hline Crt. & \multicolumn{1}{|c|}{$\begin{array}{c}\text { Checklist } \\
\text { enquiry }\end{array}$} & $\begin{array}{c}\text { Responses } \\
\text { given }\end{array}$ & $\begin{array}{c}\text { Total } \\
\text { participants }\end{array}$ & Percentage & $\begin{array}{c}\text { Reason(s) } \\
\text { For "Yes" or "No" }\end{array}$ \\
\hline 1. & $\begin{array}{l}\text { I am able to } \\
\text { apply the } \\
\text { framework }\end{array}$ & 9 & 20 & 45 & None \\
\hline 2. & $\begin{array}{l}\text { I can partially } \\
\text { apply the } \\
\text { framework }\end{array}$ & 3 & 20 & 15 & None \\
\hline 3. & $\begin{array}{l}\text { I am not able to } \\
\text { apply the } \\
\text { framework }\end{array}$ & 8 & 20 & 40 & $\begin{array}{l}\text { Some of the } \\
\text { components are not } \\
\text { clear to us. }\end{array}$ \\
\hline
\end{tabular}

Box 1: Challenges about the scientific indicators.

1. "They are good but you need time to understand them."

2. "They should be revised."

3. "They are based on books."

4. "They are for those who went to school."

5. "They should be simplified."

6. "They are cost oriented."

7. "They are difficult to follow."

8. "They can be improved."

9. "They are for educated people.” 
Table 4: The scientific framework of Indicators applied in the study area since 1990s. (Source: English et al., 1994, 1997; Hill et al., 2005; KICAMP, 2005).

\begin{tabular}{|c|c|}
\hline $\begin{array}{l}\text { Scientific attributes/indicators } \\
\text { for monitoring mangroves }\end{array}$ & $\begin{array}{l}\text { Scientific attributes/indicators } \\
\text { for monitoring mangrove-based fisheries }\end{array}$ \\
\hline $\begin{array}{ll}\text { - } & \text { Community structure and } \\
& \text { Biomass } \\
\text { - } & \text { Primary Productivity } \\
\text { - } & \text { Leaf litter production } \\
\text { - } & \text { Soil characteristics } \\
\text { - } & \text { Area coverage } \\
\text { - } & \text { Species composition and } \\
& \text { diversity } \\
\text { - } & \text { Dynamics (change) }\end{array}$ & $\begin{array}{l}\text { - Population size } \\
\text { - } \text { Population structure } \\
\text { - } \text { Heeding success } \\
\text { - Type of gear used to catch the fish } \\
\text { - } \text { Distance to fishing ground } \\
\text { - Type of vessel used and size } \\
\text { - Means of vessel propulsion } \\
\text { - Incidental catches of endangered } \\
\end{array}$ \\
\hline
\end{tabular}

\section{RESULTS AND DISCUSSION}

Challenges raised from the Experiential Learning Intervention Workshop suggest a list of conditions that determine or necessitate the adaption of scientific knowledge in a mangrove monitoring scenario. These include the level of education that the participating group has, level of participation opted for, contextual realities on ground, consideration of the potential input that target communities have, and the level of structures opted for.

\section{Level of education}

One of the conditions that require attention is, for example, the capacity of the target communities to adapt and apply scientific methodologies. This appears to be necessary since literacy levels, especially in the developing countries, vary across regions. In one of the studies carried out in the eastern coast of Tanzania by a team of marine scientists, a random sample of 145 individuals was taken for purposes of analysing their socio-economic status, including the level of education. The results indicated that the level of education among target communities was very low. About one-third of the population (31\%) had no formal education at all, $26 \%$ had reached only up to standard IV, $3 \%$ had completed standard VII, and only $2 \%$ had received post-primary education. The study also revealed that women had generally "lower literacy and educational levels" than men (Wagner et al., 2001).

In another coastal monitoring context, an assessment was carried out in the same area by one of the capacity building programmes through a two-day participatory workshop to establish the capacity of coastal communities and local government staff to understand and apply the adapted monitoring plan. It was observed that the latter were more conversant with the indicators and methodologies used in the plan than the former (KICAMP, 2004). The difference was scribed to the varying levels of formal education between the two. The level of "practical experience" amongst the two groups could not be taken as a confounding factor since both participants were exposed to the plan at the same time and had no prior knowledge of the same. This suggests that there is a close link between literacy and numeracy skills and the capacity to adapt and apply scientific indicators and methodologies. In other words, understanding is a prerequisite for taking part effectively in the practice. 
Reed et al. (2010) argue that for learning to occur in a community of practice (as it is the case with the participatory coastal monitoring initiatives), involved individuals must demonstrate a change in "understanding", and be able to share their knowledge with other participants to the level that will attract more involvement and wider participation of other community members in the same practice.

\section{Level of participation}

The second condition that comes out so strongly in the community-based monitoring is deciding the level of participation that is required for community involvement. This involves taking part in choosing educational tools that are suitable in the learners' context. It depicts a doctor-patient scenario where involvement and willingness of the patient in the prescription process is necessary. Some facilitators tend to assume that target communities (learners) may only be involved at particular levels of the initiatives, whereas others do not involve them at all (Songorwa, 1999). Campbell and Vainio-Mattila (2003) insist that target communities should influence the conception, design, and implementation of the introduced initiatives. Influencing the conception and the design implies taking part in deciding the structure, approach, materials that suit their need and situations that address the actual reality in a coastal and marine setting.

There are two options that are normally preferred by facilitators when laying down strategies for participatory learning initiatives at local level. The first option is to use adapted tools such as models, framework of indicators, plans, and any other interventional methods or techniques (KICAMP, 2005). This approach is common and mostly favoured as discussed earlier in the introduction part. The second option sets opportunities for target communities to create their own monitoring tools depending on conditions that prevail in their context and thereafter apply them. The latter option seems to carry on board the real meaning of participation or "participatory approaches" and is probably least favoured. Choosing either of the two needs to be decided and agreed by involved individuals and social groups in everycommunity based scenario. Comprehension of the said tools emerge to be an important factor since as discussed earlier, learning can hardly occur without understanding (Reed et al., 2010). Campbell and Vainio-Mattila (2003) argue that communities are not "passive bystanders" in the on-going or introduced initiatives but have to be actively engaged in the negotiations that determine what those initiatives will look like.

\section{Contextual realities on ground}

It is observed that long-term changes in the initiatives that local communities are involved in may only be realised or experienced if an emphasis will be laid on "situated knowledge”. Campbell and Vainio-Mattila (2003) defines this as "a process whereby access to the information, and control over knowledge use shifts from experts and scientists to the people whose lives are being affected".

Situating knowledge in a particular learning context requires consideration of various elements. Indicator development for the monitoring of mangroves as a practice that stimulates learning should thus be rooted in contextual realities. Arguing in favour of prioritizing contextual information Glahn et al., (2007) provide the following description: "Actors depend on indicators in order to organise, orientate and navigate through complex environment by utilising contextual information. Contextual information on the learning processes has been proven as important to support the learning processes. It stimulates the learners' engagement in and commitment to collaborating processes; it helps to raise awareness of, and stimulates reflection about acquired competences; it supports thoughtful behaviour in navigation and learning paths." 
Glahn et al. (2007) not only insist on developing indicators that are relevant to the context within which they will be applied, but also bring into view the fact that the processes which lead to development indicators are closely linked to learning. In other words, it implies that involving local actors such as coastal communities in such process or practice creates opportunities for them to learn from each other, and therefore understand better both the context and the indicators they have developed. This may also suggest that imposing or causing actors to adapt indicators from other contexts deprives them of opportunities for learning and compels them to apply tools that are not their own creation.

According to ITAD (1997), the measures that the indicators suggest must be contextually appropriate, clear and acceptable to target communities to avoid misrepresentation of information, over-reporting or underreporting of events. The indicators should also be cost-effective, relevant to the context, easy to apply or use. Scheltinga et al. (2004) also emphasize the need to avoid complexity by also avoiding technical abstractions and embarking on simple processes that can be easily be measured, analysed, and interpreted by involved communities.

Rydin et al. (2003) noted a wave of change in indicator development, from a "technical" process which involve experts (at global level) to a participatory process which focuses on understanding the local context within which the indicators are being developed as a process which focuses on the relationship between lay people and experts. They argue that if indicator development is no longer a technical issue, then it should not be left to experts, but rather to people who are directly affected by the situation. Indicator development should thus be centred on the learner's situation or context, and not on "static" approaches which according to Glahn et al. (2007) follow a fixed set of rules in the process of collecting aggregating and indicating information to learners.

As indicated earlier, comprehension is a key element in the learning process without which learning of whatever kind can hardly be attained or attracts a wider level (Reed et al., 2010). Reed et al. (2006) identified two key criteria for indicators: ability of users (learners) to apply them and their relevance at local level as discussed earlier. For users of the indicators to meet the first criterion (ability to apply them), they must first comprehend them. The level of comprehension amongst them will depend on the level reification and abstraction that underpin their involvement in the initiatives they are undertaking.

If for example, the development of the said indicators pursued a formal natural science route, common people who have never had access to participate in "formal learning" can hardly understand them. But if the abstractions favour the local context and the learners or users are part of the process that leads to development of such indicators, they are likely not only to understand the indicators but interact and share new knowledge with other local actors.

It is also wise to learn from target communities whether or not there are cultural aspects that need to be addressed or considered in the monitoring plans prior to adapting any frameworks or tools. This is an important aspect since culture in most societies and is closely linked or related to moral aspects (Medin and Atran, 2008). When it is regarded as a moral duty, it may create a binding situation which compels a defined community to abide by what is believed to be "morally" acceptable. In this manner, culture may either act as an enabler or constraining factor. For example, if mangrove forest sites are regarded or designated by a particular local community as being sacred, visiting such areas may be restricted to specified individuals and opportunities for other member of the community including the facilitators to undertake conservation or management activities, may be limited. 
Development of monitoring indicators should thus consider what may be acceptable in a particular culture and what may not. This can be reached by consulting target social groups and encouraging processes that will allow them to take part at all levels of the monitoring plan, as well as through the implementation process.

\section{The level of structures opted for}

The kind of structures preferred by facilitators may well affect the process of developing community-based monitoring programmes and ultimately enable or constrain the learning process. Reed et al. (2006) present two paradigms that determine the development of indicators in the local context as being the top-down and bottom-up. The process that leads to development of indicators under the top-down paradigm tend to exclude contextual aspects and do not encourage consultation of local communities as does the bottom-up approach. Indicators that result from the latter "provide a more contextualised understanding of local issues" and guarantee sustainability, ownership and accountability of participating learners. Fraser et al. (2005) remind development experts (facilitators) to ensure that the process of choosing indicators should consider their relevance to local situations.

\section{Consideration of local input}

There is evidence that local communities that are involved in participatory monitoring of coastal and marine resources are hardly asked to share experiences and situated knowledge for purposes of informing the conception and implementation of planned initiatives. Campbell and Vainio-Mattila (2003) present two cases where marine scientists "continued to rely heavily on western scientific criteria" in determining conservation practices.

Fraser et al. (2005) insist on the fact that "local input" is required when developing community based monitoring indicators in order to "accurately measure what is locally important". Commenting on the need to consider local knowledge in the monitoring process Berkes (2012) states: "As people with detailed understanding of the environment and accumulation of observations over generations, indigenous groups have a special place in community-based monitoring. As well, it is becoming clear that many indigenous groups have developed their own traditional monitoring based on their own ways of knowing. Most traditional monitoring methods used by indigenous people are rapid, low-cost, and easily comprehensible by harvesters themselves as they hunt, fish, and gather the forest products".

Berkes (2008) observes that insights of indigenous wisdom offer great potential for broadening epistemological access, given the difficulties and limitations of accessing and using scientific knowledge in addressing complex ecological challenges. Such difficulties emerge when scientific institutions favour the language of description and methodologies that are too hard for non-specialists at community level to follow, leading to lack of epistemological access between scientific institutions and local communities (Reed et al., 2006).

Reid et al. (2006) advise that ways have to be explored in which scientific (western) and traditional knowledge can be used together, and conditions necessary for such integration need to be better understood.

\section{Developing of an alternative framework of indicators as under labourer for the existing scientific framework}

To examine the existing local knowledge as an input for addressing various challenges that are associated with the adaption and application of scientific indicators, open-ended questionnaires were administered to selected mangrove restorers, fishers and local elders to guide in-depth individual interviews that would yield traditional ecological knowledge on the trends, changes, threats and condition of mangroves and fisheries that use them as key habitats. Such forms of inquiry are applied when researchers seek to capture in-depth data in specific 
cases (Boyce and Neale, 2006). Interviews with individual fishers were carried out near fishlanding sites to allow them to choose at least three kinds of mangrove-based fisheries as objects for abstraction and representation. Interviews with individual mangrove restorers were held near or in the mangrove sites depending on the tide level and ability of participants to cross muddy areas to desired positions (where they could clearly see or touch mangrove species while they continued to describe them). Interviews with the local elders were held in their home compounds or near mangrove sites depending on age, physical well-being, and preferences.

The interview processes for each of the participants' groups (fishers, mangrove restorers, and elders) were culminated in three Focus Group Discussions (FGDs). Berkes (2008) argues that individual knowledge and experience tend to be distinct, but it is enriched by the knowledge of the group and is "shaped by the ways of knowing of the group". It is on this ground that this study opted for FGDs as a second medium of enquiry or a culminatingpoint for individual abstractions, conceptualisations, and representations of traditional ecological knowledge (TEK). FGD inquiry was also considered useful in this context since it allows researchers to probe, places research participants in natural or real situations, can be easily understood, and has high "face validity" (Krueger, 2000). FGD also provides speedy results, and it follows socially oriented procedures. Moreover, the method allows the researcher to gain information on "how people think, perceive, give ideas, and share experiences" (Wilkinson, 2000).

\section{Analysis of Traditional Ecological Knowledge (TEK)}

Emerging data from individual in-depth interviews, focus groups and experiential learning cycles were captured and coded into specific themes/sub-themes. This process was followed by assigning participants' representations to emerging themes or sub-themes and analysing their ontological or epistemology nature based on local experiences. The focus was to examine the potential contribution of traditional ecological knowledge to the development of monitoring indicators that incorporate contextual, social and cultural realities.

Key themes emerging from the processes of coding included: (1) the physical condition of mangroves and fisheries that use them as habitat, (2) threats that face the mangrove ecosystem in general, (3) changes that occur in the mangrove ecosystem, and (4) trends of mangrove and fisheries species in the mangrove ecosystem. Obtained data were further discussed by research participants, assigned to the four (4) key themes and used to develop a draft framework of Traditional Ecological Indicators (TEK) which had the potential of being added or integrated with the existing scientific framework for the purposes of enhancing learning. This was carried out through series of four Focus Groups held in the study area between January and March 2012. The successful development of the draft TEK framework uncovers the curiosity of mangrove restorers and fishers to respond to the challenges they had experienced earlier while applying the scientific framework of indicators and associated methodologies (Tabs. 1 and 2; Box 1), which affect participatory monitoring practices and limit learning in the eastern coast of Tanzania.

Attributes developed by coastal communities for underlabouring (supporting) scientific mangrove indicators

- Drying or withering of mangrove species;

- Presence of stumps;

- Soil type;

- Presence of invasive species; 
- Presence of charcoal kilns;

- Presence of saltpans;

- Physical outlook of plants (leaves, roots, stem, branches, epical bud, shoots);

- Dense canopy;

- Accumulation of solid waste in the mangrove;

- Presence of invertebrates and vertebrates.

Description of the attributes/indicators as perceived by coastal communities

a) Drying or withering of mangrove species

Drying or withering of mangroves is associated with human induced threats, disease or natural disasters occurring in the coastal areas such as tsunami, invasive species, and deprived nutrient levels. Human induced factors can be mangrove cutting for domestic and commercial use, root digging in search of baits (mainly earthworms) and accumulation of solid waste around young plants. Monitoring techniques that can lead to drawing conclusion that the plant has withered/dried includes; physical observation and inspection of leaves, branches, and the stem. A mangrove plant that is under this kind of threat will indicate a condition of dried/drying leaves, falling of leaves on ground and possibly drying branches.

b) Presence of mangrove stumps

The presence of mangrove stumps in the mangrove forest indicates that there has been mangrove clearance in the area. Stumps can indicate the extent of damage and suggest the time when such threat occurred. This is possible since old stumps are dry and their colour is different from the new stumps. The level or extent of damage will be established by counting down the number of stumps and by making strides (counting human steps). Identification of the affected mangrove species is also possible and can be done by observing neighbouring species. If nearby species are Mchu/Mchwi (Avicennia marina), then the damaged species will be the same, since species of the same kind or type tend to grow together.

c) Soil type

Soft-muddy soils allow plant-roots to penetrate deeper in the ground and absorb nutrients. Plants that grow in this area are likely to be healthy. Their leaves remain green and their heights higher than those in rocky areas. On the other hand, rocky areas suggest that mangrove roots cannot easily penetrate the ground. Such species will appear short, with roots coined on top of the ground and colour of their leaves will remain between green and yellow. Rich soil will also show black colour while rocky and poor soil will depict a yellowish or reddish colour. The indicator for the health status will be the type of soil, height of plants, soil colour and colour of leaves. Involved techniques will involve examining whether the soil is soft-muddy or rocky and indicating it in the report form and carefully identifying the colour of leaves and stating it, and thereafter use agreed indigenous measures (pima) in establishing the plant height.

d) Presence of invasive species

Presence of invasive species suggests that mangrove plants are subject to competition for nutrients with species that do not belong to their colony (intruders). These may encroach on the mangrove from nearby ecosystems, or may be caused and accelerated by other factors such as human activities or natural causes. To determine whether there are invasive species in the mangroves, monitoring teams can do physical observation around different mangrove species, and inspecting specific parts such as plant canopy, the ground and any other possible areas. Species that are not of mangrove origin can be seen or identified by naked eyes. Other identification techniques include smelling, and comparison (comparing their leaves with mangrove species). 


\section{e) Presence of charcoal kilns}

The presence of charcoal kilns in the mangrove forest suggests there has been clearing of plants in the area and it is therefore a good indicator that destruction of mangrove species has occurred. The extent of damage will depend on the number of charcoal kilns seen in the area and also the number of stumps that may be associated with such a clearance. The most affected species can also be identified by observing their proximity to their "mother colonies".

f) Presence of saltpans

Like charcoal kilns, the presences of saltpans indicate that there has been a significant clearance of mangrove species in the area. Saltpans require enough land-space for salt making; and mangrove areas prove to be suitable for this kind of economic activity since they allow lodging of saline water from the ocean; which is exposed to evaporate under controlled environment, leaving behind salt as an output or product. Establishing the extent of damage can be done by counting the number of saltpans and striding the size of each saltpan. Counting stumps is not possible in this case since mangrove clearance for saltpans is normally accompanied by uprooting and levelling of the area. The most affected species can also be observed and recorded.

g) Look of the plant species (leaves, roots, stem, branches, epical bud, and shoots)

Physical look of the plant is among the key indicators of good or bad plant health among indigenous coastal communities. Plant leaves, roots, shoots, stem, branch, epical bud and length are themselves independent indicators which can show the status of a plant.

Leaves. Mangrove leaves range from green to evergreen colour depending on the species type. Change in colour from evergreen to yellow, pale, or red, suggests that either there is a change in season or a threat from both natural and human induced factors. Monitoring teams may closely make an inspection to determine the cause for change in colour and establish whether it is a result of poor soil, human threats or other causes.

Roots. Plants with roots that are fully covered by the soil are considered to be stable and safe from human induced activities and wild animals. Exposed roots indicate a short lifecycle of a plant since roots hold and keep it in contact with the nutrients from the soil. Fishers tend to dig out earth worms from mangrove roots as baits that might attract particular fish species. Wild animals also dig out various worms for food. Carrying out a careful inspection beneath mangrove species can lead to establishing whether the roots are fully covered or partially covered, fully exposed or partially exposed. The status of identified species will be established based on the above factors.

Stem. Plant stem indicates its width and level of nourishment. A good looking stem suggests that the entire plant is likely to be healthy. Peeling of tree-bark around the stem may lead to mortality of mangrove species. The stem is regarded as a store for the plant food. Its damage or destruction may lead to starvation of the plant and ultimately death. Physical inspection of the stem (damaged or undamaged) and its size (width) may help in establishing the plant's health status. A clear observation of the plant-bark to identify possible damages and likely cause will also help. Measuring of stem-width can be done by using a tape measure or traditional measures (pima).

Branches. Straight branches with aligned bark-thickness show continuous growth. Past records in Mkinga show that mangrove branches are selectively cleared for boat making and construction of residential apartments. In such a process, young branches are damaged and dwarfed. Branch straightness and the presence or absence of remarkable damage in mangrove branches in selected mangrove plots will help in establishing their health status. 
Epical bud. Removal of the epical bud suggests a limitation of plant's growth upward, hence limited length. The presence or absence of the epical bud therefore will determine whether a particular mangrove plant is growing upward or not. Inspecting plant canopy or top will help the monitoring team to establish whether the epical bud is present or absent.

Plant shoots. The presence of shoots around the plant suggests a promising future of the forest-growth or recovery from threats. The absence may suggest an ageing forest or seasonal changes. Plant shoots in specified plots will be traced and counted. A second inspection will be done to establish whether they are sparsely distributed or concentrated in particular plots, followed by a decision whether they indicate a good or bad mangrove health.

h) Dense canopy

A good aligned canopy with a distinguished green colour suggests that the forest is in good health. Poorly spaced mangrove species depict a spaced canopy that is only good in some parts of the forest and poor in other parts. Appearance of the forest canopy from at least a distance of $300 \mathrm{~m}$, the number of bare spaces in the identified plots and the general outlook of the forest colour will help in establishing the health status of the mangrove forest. Monitoring techniques will thus involve standing within a range of at least $300 \mathrm{~m}$ away to observe the appearance of the canopy and counting bare spaces in the specified plots and ranking the canopy as either good or bad.

i) Accumulation of solid waste in the mangrove

Accumulation of solid waste in the mangroves impairs growth of plant-seedlings and shoots. Discarded fishing nets, clothes, plastic materials, ropes, broken boats/fishing vessels and other forms of waste that can trap seedlings and shoots are harmful to the mangroves and also to other vertebrates and invertebrates, such as juvenile fish, that use mangroves as a habitat. Observation of the presence or absence of solid waste in the mangroves will therefore help to establish whether such a threat exists or not. It may also be possible to locate the source of waste in order to address the threat.

j) Presence of invertebrates and vertebrates

The crawling organisms presence in the soil/ground that harbours mangrove species may suggest threats to seedlings and plant shoots. Other organisms like worms will generally indicate good aeration of the soil. A notable indicator in this case will be the presence or absence of insects or any other marine organisms that are considered having positive or negative relationship with the plant. A careful observation and identification of the encroaching organisms near mangrove species and particularly in the shoots, seedlings, and roots will be required.

Indicators developed for underlabouring scientific fisheries indicators

- Gills colour;

- Colour of eyes (pale/brownish are bad);

- Skin condition (soft/hard) bouncing back or not;

- Presence of wounds/scars/bruises;

- Weight in relation to fish size;

- Condition of the air bladder (good or bad);

- Presence or absence of body fats;

- Fish shape (physical appearance);

- Catch frequency of various species (most fished fisheries/least fished);

- Frequency of blasts in case of dynamite fishing;

- Number of fishers involved in mangrove fishing in the area;

- Body parts (missing or damaged). 


\section{Description of the attributes/indicators}

\section{1) Gills colour}

The normal gill colour for a fish that has just been fished-out is supposed to be reddish. If the gills display a pale or whitish colour then the monitoring team may consider that particular species as unhealthy. Possible assumptions for the bad health status may include the possibility that such a fish was already weak before being fished out. Traditional methods or techniques for detecting the status of gills include physical observation of the gills in selected fish-landing sites and recording observations in a monitoring sheet.

2) Eye colour

Colour of the fish-eye may indicate whether particular species is healthy or not. Pale and brownish colours suggest poor health. Besides those two "bad colours", different fish may have different appearance of eyes depending on their types. Key methods for accessing information that capture such an indicator is to observe caught fish in selected fish-landing sites and involve experienced fishers who can easily distinguish eye colours of different fish species.

\section{3) Skin condition}

Skin may also indicate the health status of a fish. A healthy fish that has just been fished out, when pressed hard, its skin bounces back to its original form. Unhealthy fish when pressed with the thumb does not bounce back, but rather attaches itself to the bones/flesh and leaves the thumb's mark in the pressed area. Identifying healthy fish through this indicator can be done near fishing-land sites. Other collected information that may go along with the above indicator may include recording of the species type and whether it is a juvenile or an adult fish. This may help to explain the category of affected species and guide management plans.

4) Presence of wound/scars/bruises

The presence of wounds/scars/and bruises in a fish that is displayed in the fish market or landsite suggests that a particular fish is not healthy. Wounds may suggest that the concerned fish species might have sustained injuries from hooking, dynamite blasts, or any other causes, including escape from natural predators, and that its health status must thus have been affected. Confirmation of the fish health status can therefore, be done by examining whether there is any piece of hook hanging around the throat and in the stomach, and the presence of wounds, scars and bruises. This physical inspection or observation has to be carried out in a nearby or designated fish-landing site. Records of availability of scars and possible cause of injuries will be recorded in the monitoring sheet or form.

5) Weight in relation to fish size

Fishers believe that fish weight is proportional to its size. Any mismatch may suggest that there is a health problem. Fishes with certain length are expected to weigh according to fisher's expectations. This requirement varies among species. Mangrove-based fish species such as mudskipper have average length and weight than can easily be estimated by local fishers. Physical observation of caught fish may be verified by weighing them out and taking metre-measurements. After that, fishers may link fish-weight relationship to their health status.

6) Condition of the air bladder

A damaged fish airbladder can be an indicator for fishing with dynamite. When the bladder is intact, it indicates that fish has been fished out using common fishing gears. Confirmation of using fishing gear may be done through physical inspection of fishes in a landing site. Hooked fishes will show scars. A damaged air bladder is mainly used in establishing whether dynamite fishing was used or not. Information as to whether the fish airbladder was intact or damaged can be recorded in special forms/monitoring sheets. 
7) Presence or absence of body fats

The presence of fats in a fish suggests that it is in good health. On the other hand, fish that lack fats in their body are described as being skinny and unhealthy and even not suitable for human consumption. To detect body fats, fishers may look around the abdomen and examine the fish body alignment. Breeding fisheries are regarded as having such indicators and are thus good in health. In instances where the monitoring team may not be able to directly use local experiences to establish whether a particular fish has body fats or not, the abdominal part may be parted (using agreed devices such as a sharp knife) to see what is inside and establish the premise. Records of the number of fattened-fish against those which are not can be taken by the team.

8) Fish shape

Physical appearance of caught fish or their shapes may indicate their health. Thin, small and dormant fish species are generally regarded as being unhealthy. Big and huge species are linked to good health status. If, for instance, mullet species are by average huge, any caught mullet species that may appear long but thin, unlike the majority of other species will be considered as having poor health. Collecting information for the above particular indicator may involve physical observation of fish in designated land sites or markets. Records that are associated with size may be recorded using tape measures, and weighing measurements.

9) Catch frequency of various species (most/least fished fish species)

Catch frequency may be used as an indicator for species abundance or decline. Those that are caught on regular basis may be regarded as being abundant and those that are rarely fished may be regarded as "endangered", and therefore, inform management or conservation decisions. Collecting information or data that indicates catch frequency per species can be done at fish landing sites or markets, using special forms or sheets.

10) Frequency of blasts

Blasts frequency in ocean indicates that "dynamite fishing" is likely to be taking place. This information can be collected by counting blasts heard per day or week. Some members of the monitoring team may be assigned the role of recording frequencies of dynamite blasts and report cumulative blasts during periodical monitoring of fisheries resources.

11) Number of fishers involved in mangrove fishing in the area

The number of fishers involved in mangrove-based fishing may indicate whether there is fishing pressure in the mangrove or not. A small number may suggest that fish-growth is assured, as more juvenile fish in the mangroves (as nursery grounds) are allowed to grow to maturity level and also the possibility of having breeding species which spend some time in the mangroves in spawning seasons to survive longer. More fishers, on the contrary, may suggest a future decline in fish catch and possibly "extinction" of mangrove fisheries. Information or data about this particular indicator can be accessed by making inquiries among fishers about the number of fishers who are specialized in mangrove fishing and keep on updating the list periodically.

12) Body parts (missing or damaged)

Some fish may have missing or damaged body parts such as tails, gills, fins, eyes, or cut mouth. These may suggest that involved fisheries are physical impaired and are therefore, not considered as being healthy. Possible causes for this condition include, dynamite fishing and the use of unfriendly fishing gears. Fisheries with missing or damaged parts can be directly observed from nearby fish-landing sites and recorded in special forms. Records should indicate the affected part, species type, and age (juvenile or adult). 
Table 5: Integrated monitoring framework for mangrove (TEK and scientific indicators).

\begin{tabular}{|c|c|c|c|c|}
\hline Crt. & Attribute & Indicator & Nature of the indicator & Monitoring technique/method \\
\hline 1. & $\begin{array}{c}\text { Soil } \\
\text { characteristics }\end{array}$ & $\begin{array}{l}\text { Soil type and } \\
\text { colour: Muddy- } \\
\text { black soils } \\
\text { indicate high } \\
\text { nutrients; rocky } \\
\text { reddish or } \\
\text { yellowish } \\
\text { indicate poor } \\
\text { soil. } \\
\end{array}$ & TEK/Scientific & $\begin{array}{l}\text { Physical observation of soil } \\
\text { layers and colours and } \\
\text { recording observed details. }\end{array}$ \\
\hline 2. & $\begin{array}{l}\text { Species } \\
\text { composition } \\
\text { and diversity }\end{array}$ & Area coverage & Scientific/TEK & $\begin{array}{l}\text { Dividing mangroves into } \\
\text { specific plots, taking } \\
\text { strides/metre measurements of } \\
\text { plot size, counting individual } \\
\text { plants per plot, observing and } \\
\text { recording dominant species per } \\
\text { plot and recording total young } \\
\text { and mature species. }\end{array}$ \\
\hline 3. & $\begin{array}{l}\text { Dynamics } \\
\text { (change) }\end{array}$ & $\begin{array}{l}\text { Physical outlook } \\
\text { of plant species: } \\
\text { leaves, roots, } \\
\text { stem, branches, } \\
\text { epical bud and } \\
\text { shoots. }\end{array}$ & TEK & $\begin{array}{l}\text { Observing leaf-colour whether } \\
\text { is ever-green (good), pale/red } \\
\text { (poor) and yellow (very poor), } \\
\text { indicating the cause of change } \\
\text { (e.g. poor soil, human threats, } \\
\text { or natural). Observing whether } \\
\text { the roots are fully covered by } \\
\text { the soil, exposed or partially } \\
\text { exposed; check the stem (is its } \\
\text { bark peeled off or not); any } \\
\text { threats to the branches, and } \\
\text { shoots? Epical-bud removed or } \\
\text { not? }\end{array}$ \\
\hline 4. & $\begin{array}{l}\text { Presence of } \\
\text { mangrove } \\
\text { stumps in area }\end{array}$ & $\begin{array}{l}\text { Number of } \\
\text { stumps in the } \\
\text { mangrove area }\end{array}$ & TEK & $\begin{array}{l}\text { Counting the number of } \\
\text { stumps, taking strides or meter } \\
\text { measurements to establish the } \\
\text { size of damaged area. }\end{array}$ \\
\hline 5. & $\begin{array}{l}\text { Drying or } \\
\text { withering } \\
\text { mangrove } \\
\text { species }\end{array}$ & $\begin{array}{l}\text { Number and } \\
\text { type of affected } \\
\text { mangrove } \\
\text { species }\end{array}$ & TEK & $\begin{array}{c}\text { Physical observation of leaves, } \\
\text { branches, and stem per plot } \\
\text { and recording observed } \\
\text { condition. }\end{array}$ \\
\hline 6. & $\begin{array}{l}\text { Presence of } \\
\text { invasive } \\
\text { species }\end{array}$ & $\begin{array}{l}\text { Type of } \\
\text { invasive } \\
\text { species, size of } \\
\text { the area } \\
\text { covered, and } \\
\text { number of } \\
\text { affected } \\
\text { mangrove trees }\end{array}$ & TEK & $\begin{array}{l}\text { Inspecting specific parts such } \\
\text { as the tree canopy, the ground } \\
\text { recording observed details. } \\
\text { Area covered by invasive } \\
\text { species can be measured by } \\
\text { metre or strides depending on } \\
\text { the affected part. }\end{array}$ \\
\hline
\end{tabular}


Table 5 (continuing): Integrated monitoring framework for mangrove (TEK and scientific indicators).

\begin{tabular}{|c|c|c|c|c|}
\hline Crt. & Attribute & Indicator & Nature of the indicator & Monitoring technique/method \\
\hline 7. & $\begin{array}{c}\text { Presence of } \\
\text { charcoal kilns }\end{array}$ & $\begin{array}{c}\text { Number of } \\
\text { charcoal kilns in } \\
\text { the mangrove } \\
\text { area }\end{array}$ & TEK & $\begin{array}{l}\text { Physical observation and } \\
\text { recording of details. }\end{array}$ \\
\hline 8. & $\begin{array}{l}\text { Presence of } \\
\text { saltpans }\end{array}$ & $\begin{array}{l}\text { Number of } \\
\text { saltpans in the } \\
\text { mangrove area, } \\
\text { size of the } \\
\text { damaged area. }\end{array}$ & TEK & $\begin{array}{l}\text { Physical observation of the } \\
\text { affected area and taking strides } \\
\text { or metre measurements to } \\
\text { establish the size of the } \\
\text { damaged area. }\end{array}$ \\
\hline 9. & Dense canopy & $\begin{array}{c}\text { Canopy } \\
\text { appearance } \\
\text { (thick or poorly } \\
\text { distributed), and } \\
\text { number of open } \\
\text { spaces/gaps in } \\
\text { the mangrove } \\
\text { per plot. }\end{array}$ & TEK & $\begin{array}{l}\text { Observing the appearance of } \\
\text { mangroves from at least a } \\
\text { distance of } 300 \text { metres, and } \\
\text { counting the number of open } \\
\text { spaces/gaps per plot. }\end{array}$ \\
\hline 10. & Solid waste & $\begin{array}{l}\text { Accumulation } \\
\text { of solid waste in } \\
\text { the mangroves }\end{array}$ & TEK & $\begin{array}{c}\text { Observing the presence or } \\
\text { absence of solid waste in the } \\
\text { mangrove and classifying the } \\
\text { kind of waste trapped in the } \\
\text { mangroves (e.g. plastic, broken } \\
\text { boats, discarded fishing nets, } \\
\text { clothes, ropes, etc.) and } \\
\text { indicating affected mangrove } \\
\text { species }\end{array}$ \\
\hline 11. & $\begin{array}{c}\text { Presence of } \\
\text { invertebrates } \\
\text { and } \\
\text { vertebrates }\end{array}$ & $\begin{array}{l}\text { The kind of } \\
\text { vertebrates or } \\
\text { invertebrates } \\
\text { present under } \\
\text { the mangrove } \\
\text { tree }\end{array}$ & TEK & $\begin{array}{l}\text { A careful observation and } \\
\text { identification of crawling } \\
\text { organisms around the plant, } \\
\text { particularly in the roots, shoots } \\
\text { and seedlings. }\end{array}$ \\
\hline
\end{tabular}

Source: Developed from field data/ELIW 2012. 
Table 6: Integrated monitoring framework for mangrove-based fisheries (TEK and scientific indicators).

\begin{tabular}{|c|c|c|c|c|}
\hline Crt. & Attribute & Indicator & Nature of the indicator & Monitoring technique/method \\
\hline 1. & $\begin{array}{l}\text { Weight and } \\
\text { length of fish } \\
\text { by species }\end{array}$ & $\begin{array}{l}\text { Fish length and } \\
\text { weight }\end{array}$ & Scientific/TEK & $\begin{array}{l}\text { Weighing caught fish per } \\
\text { species, using a metre to } \\
\text { measure their length, and } \\
\text { comparing recorded weight of } \\
\text { selected species by size to } \\
\text { observe possible differences }\end{array}$ \\
\hline 2. & $\begin{array}{l}\text { Used fishing } \\
\text { gear }\end{array}$ & $\begin{array}{l}\text { Type of gear } \\
\text { used to catch } \\
\text { fish, } \\
\text { (unsustainable } \\
\text { gears suggest } \\
\text { threats to } \\
\text { fisheries or high } \\
\text { mortality rate } \\
\text { while } \\
\text { sustainable } \\
\text { gears indicate } \\
\text { assured future } \\
\text { birth-rates). } \\
\end{array}$ & Scientific/TEK & $\begin{array}{l}\text { Asking fishers to help in } \\
\text { identifying used fishing gears } \\
\text { and recording them. }\end{array}$ \\
\hline 3. & $\begin{array}{l}\text { Distance to } \\
\text { fishing ground }\end{array}$ & $\begin{array}{l}\text { Distance in } \\
\text { metres or } \\
\text { kilometres from } \\
\text { the take-off } \\
\text { point to the } \\
\text { fishing ground }\end{array}$ & Scientific/TEK & $\begin{array}{l}\text { Use of "estimation method" to } \\
\text { establish possible distance or } \\
\text { metered boats when such } \\
\text { equipment are available }\end{array}$ \\
\hline 4. & $\begin{array}{l}\text { Mangrove } \\
\text { fishers in the } \\
\text { area }\end{array}$ & $\begin{array}{l}\text { The number of } \\
\text { fishers involved } \\
\text { in mangrove } \\
\text { fishing in the } \\
\text { area }\end{array}$ & TEK & $\begin{array}{l}\text { Physical observation } \\
\text { (counting) and seeking } \\
\text { confirmation from fishers in } \\
\text { the area. }\end{array}$ \\
\hline 5. & $\begin{array}{c}\text { Incidental } \\
\text { catches of } \\
\text { endangered } \\
\text { species }\end{array}$ & $\begin{array}{l}\text { Number and } \\
\text { type of } \\
\text { endangered } \\
\text { species caught }\end{array}$ & Scientific/TEK & $\begin{array}{l}\text { Interviewing fishers in fish- } \\
\text { landing sites and recording } \\
\text { given information or data. }\end{array}$ \\
\hline 6. & Gills cover & $\begin{array}{l}\text { Colour of gills } \\
\text { (red colour } \\
\text { suggest good } \\
\text { health while } \\
\text { pale and whitish } \\
\text { indicate not } \\
\text { good or bad } \\
\text { health) }\end{array}$ & TEK & $\begin{array}{l}\text { Physical observation of the } \\
\text { gills at a fish-landing site and } \\
\text { recording the observed colour. }\end{array}$ \\
\hline 7. & Eye colour & $\begin{array}{l}\text { Colour of fish } \\
\text { eyes (pale and } \\
\text { brownish } \\
\text { suggest poor } \\
\text { health) }\end{array}$ & TEK & $\begin{array}{l}\text { Observing caught fish in fish- } \\
\text { landing sites, and involves } \\
\text { experienced fishers in the } \\
\text { colour identification. }\end{array}$ \\
\hline
\end{tabular}


Table 6 (continuing): Integrated monitoring framework for mangrove-based fisheries (TEK and scientific indicators).

\begin{tabular}{|c|c|c|c|c|}
\hline Crt. & Attribute & Indicator & Nature of the indicator & Monitoring technique/method \\
\hline 8. & Skin condition & $\begin{array}{l}\text { Ability of the } \\
\text { "skin" to } \\
\text { bounce back } \\
\text { when pressed/ } \\
\text { thumbed. Skin } \\
\text { of a healthy fish } \\
\text { bounces back } \\
\text { when pressed as } \\
\text { opposed to } \\
\text { unhealthy one. }\end{array}$ & TEK & $\begin{array}{l}\text { Pressing caught fish with } \\
\text { thumb at a fish-landing site to } \\
\text { observe whether the skin } \\
\text { bounces back or not, and } \\
\text { recording the observation. } \\
\text { Species type/age } \\
\text { (juvenile/mature) may also be } \\
\text { recorded to indicate the } \\
\text { affected species. }\end{array}$ \\
\hline 9. & $\begin{array}{c}\text { Wounds/scars/ } \\
\text { bruises }\end{array}$ & $\begin{array}{c}\text { Presence of } \\
\text { wounds, scars or } \\
\text { bruises indicate } \\
\text { a health threat. }\end{array}$ & TEK & $\begin{array}{l}\text { Inspection or observation of } \\
\text { wounds, scars, or bruises in a } \\
\text { nearby fish-landing site, and } \\
\text { any other threats such as } \\
\text { hanging hooks. }\end{array}$ \\
\hline 10. & $\begin{array}{l}\text { Condition of } \\
\text { fish air- } \\
\text { bladder }\end{array}$ & $\begin{array}{l}\text { A damaged fish- } \\
\text { airbladder } \\
\text { indicates the use } \\
\text { of dynamite in } \\
\text { fishing }\end{array}$ & TEK & $\begin{array}{l}\text { Physical inspection of the fish- } \\
\text { airbladder in a nearby fish- } \\
\text { landing site with the assistance } \\
\text { of experienced fishers. } \\
\text { Recording the affected species } \\
\text { by type and age } \\
\text { (juvenile/mature) }\end{array}$ \\
\hline 11. & Fish body-fats & $\begin{array}{l}\text { Presence of fats } \\
\text { in a fish } \\
\text { suggests a good } \\
\text { health while } \\
\text { those without } \\
\text { fats are regarded } \\
\text { as skinny and } \\
\text { unhealthy. }\end{array}$ & TEK & $\begin{array}{l}\text { Using allowed device (e.g. a } \\
\text { sharp knife) to inspect the } \\
\text { abdominal part and getting } \\
\text { assistance from experienced } \\
\text { fishers. }\end{array}$ \\
\hline 12. & Fish shape & $\begin{array}{c}\text { Physical } \\
\text { appearance of a } \\
\text { caught fish may } \\
\text { indicate their } \\
\text { health status. } \\
\text { Thin, small, and } \\
\text { dormant fish are } \\
\text { linked to poor } \\
\text { health while } \\
\text { huge fish are } \\
\text { associated with } \\
\text { good health. }\end{array}$ & TEK & $\begin{array}{l}\text { Physical observation of caught } \\
\text { fish in designated fish-landing- } \\
\text { site or markets to establish } \\
\text { weather caught fish are } \\
\text { regarded as having good shape } \\
\text { or not. }\end{array}$ \\
\hline 13. & $\begin{array}{l}\text { Catch } \\
\text { frequency }\end{array}$ & $\begin{array}{l}\text { Catch frequency } \\
\text { indicate } \\
\text { abundance or } \\
\text { decline of fish } \\
\text { catch. }\end{array}$ & TEK & $\begin{array}{l}\text { Record taking of most frequent } \\
\text { caught species to predict a } \\
\text { possible future decline and } \\
\text { records of rarely caught } \\
\text { species for conservations } \\
\text { decisions. }\end{array}$ \\
\hline
\end{tabular}


Table 6 (continuing): Integrated monitoring framework for mangrove-based fisheries (TEK and Scientific indicators).

\begin{tabular}{|c|c|c|c|c|}
\hline Crt. & Attribute & Indicator & Nature of the indicator & Monitoring technique/method \\
\hline 14. & $\begin{array}{c}\text { Frequency of } \\
\text { blasts }\end{array}$ & $\begin{array}{c}\text { Number of } \\
\text { dynamite blasts } \\
\text { heard per week }\end{array}$ & TEK & $\begin{array}{c}\text { Interviewing communities and } \\
\text { recording the number. }\end{array}$ \\
\hline 15. & $\begin{array}{c}\text { Missing or } \\
\text { famaged body } \\
\text { parts such as } \\
\text { eyes, tails and } \\
\text { fins. }\end{array}$ & TEK & $\begin{array}{c}\text { Physical observation of caught } \\
\text { fishes in the fish-landing-site } \\
\text { and recording of missing parts, } \\
\text { specie type and species age } \\
\text { (juvenile/adult) }\end{array}$ \\
\hline
\end{tabular}

Source: Developed from field data/ELIW 2012.

Testing of the new (integrated) framework of indicators and feedback from groups.

This was the last activity in the ELIW cycle, which allowed the participants to form three random groups and choose leaders who would preside over the monitoring exercise at the group level. Each group also appointed a recorder to record observed changes, condition, trends, and threats in the site of their choice. For feedback of the testing exercise, and individual observations see box 2 .

Box 2: Feedback made after testing the integrated framework of indicators.

We tested all indicators and recorded the required information as seen in this sheet. We did not face any difficulties. Every member participated effectively in the exercise (leader group A). We went to the eastern part of the forest and read through the indicators before testing. The indicators are easier than those in the old framework. We recorded the required information in the sheet (leader group B).

We successfully tested the indicators although there were some signs of the high tides. We did not finish all the indicators but what we did was successful, there was no problem (leader group C). As we were testing the new indicators, we found them to be simple and easier than the old ones. They are straight forward and can be done in a very short time. All group members played a role in the testing (member group B).

Those indicators were for the educated people. You could count two or three individuals who could at least use them. But these ones are simple because you just observe and record what you have observed (member group C). 


\section{CONCLUSIONS}

Scientific knowledge emerges from basic and applied research carried out in different contexts and sometimes depicting a specified level of generalization or replication. Though this knowledge can be adapted and applied in various contexts, there is a need to consider factors such as contextual realities on ground, the level of education that the beneficiaries have, level of participation that is required in particular initiatives such as monitoring of the mangrove ecosystem, the potential input that target communities have, and the level of structures that govern participatory monitoring practices in different contexts.

Well-coordinated participatory monitoring practices will not leave target communities as "bystanders" but as active participants at all levels including the decision to adapt, develop or integrate scientific and local knowledge as key ingredients of the monitoring framework. A well-coordinated mangrove monitoring initiative will thus encourage knowledge shift from experts and scientists to the people whose lives are being affected, and at the same time lead to epistemological access, where the former and the latter can share and learn from one another.

While this paper agrees that certain monitoring standards need to be met to allow scientists to share knowledge from different parts of the world, it also place emphasis on the need to secure local actor's willingness to choose the form of knowledge that will attract their active participation, accountability, comprehension, and application of preferred knowledge. This may greatly reduce or minimize the challenges that this paper brings into view and attract a wider social learning in the coastal environment. 


\section{REFERENCES}

1. Babbie E., 2001 - The Practice of Social Research, 9th Ed., Belmont, Wadsworth Thomson Learning, 116.

2. Babbie E., 2007 - The Practice of Social Research, 11th Ed., Belmont, Wadsworth Thomson Learning, 116.

3. $\quad$ Berkes F., 2008 - Sacred Ecology, 2nd Ed., New York, Routledge.

4. Berkes F., 2012 - Sacred Ecology, 3rd Ed., New York, Routledge.

5. Boyce C. and Neale P., 2006 - Conducting in-depth interviews, A Guide for Designing and Conducting in-depth Interviews for Evaluation Input, Pathfinder International.

6. Breen H., 2013 - Collaboration in the Online Educational Setting: A concept Analysis, Nursing Forum, 48, 262-270.

7. Campbell L. M., 2000 - Human need in rural developing areas: Perceptions of wildlife conservation experts, The Canadian Geographer, 44, 2, 167-181.

8. Campbell L. M, and Vanio-Matilla A., 2003 - Participatory Development Community-Based Conservation: Opportunities Missed for Lessons Learned, Human Ecology, 31, 3, 417-437.

9. English S., Wilkison C. and Baker V. (eds), 1994 - Survey Manual for Tropical Marine Resources, ASEAN Australian Marine Science Project: Living Coastal Resources, Townville, Australian Institute of Marine Science.

10. English S., Wilkinson C. and Baker V. (eds), 1997 - Survey Manual for Tropical Marine resources (2nd Ed.), AIMS, Townville: AIMS.

11. Fraser E. D. G., Dougill A. J., Mabee W. E., Reed M. and McAlpine P., 2005 - Bottom up and top down: Analysis of participatory processes for sustainability indicator identification as pathway to community empowerment and sustainable environmental management, Journal of Environmental Management, 78, 114-127.

12. Glahn C., Specht M. and Koper R., 2007 - Creating new learning experiences on global scale, Berlin, Springer.

13. Hammond L., Austin K., Orcutt S. and Rosso J., 2001 - How people learn: Introduction to learning theories, Stanford: Stanford University, 2-22.

14. Hill D., Fasham M., Tucker G., Shewry M. and Shaw P. (eds), 2005 - Handbook of Biodiversity Methods: Survey, Evaluation and Monitoring, New York, Cambridge University Press, 106-236.

15. ITAD, 1997 - IUCN Monitoring and Evaluation Initiative, London, ITAD.

16. Kinondoni Integrated Coastal Area Management Programme (KICAMP), 2005 - Phase One Final Report, Dar es Salaam.

17. Krueger R. A., 2000 - Focus Groups, 2nd Ed., A practical Guide for Applied Research, Thousand Oaks, Sage.

18. Kuper M., Dionnet M., Hammani A., Bekkar Y., Garin P. and Bluemling B., 2009 - Supporting the shift from state water to community water: Lessons from a social learning approach to design joint irrigation projects in Morroco, Ecology and Society, 14, 19.

19. Leys A. and Vanclay J., 2010 - Stakeholder engagement in social learning to resolve controversies over-land use change to plantation forestry, Regional Environmental Change, 11, 175-190.

20. Lotz-Sisitka H. B. (ed.), 2012 - (Re) views on Social Learning Literature: A Monograph for Social learning Researchers in natural resources management and environmental education. Grahamstown/Howick: Environmental Learning Research Centre, Rhodes University/EEASA/SADC REEP.

21. Medin D. and Atran S., 2008 - The Native Mind and the Cultural Construction of Nature. Massachusetts: Massachusetts Institute of Technology.

22. Mostert E., Pahl-Wostl C., Rees Y., Searle B., Tabara D. and Tippett J., 2007 - Social Learning in European River-Basin Management: Barriers and Fostering Mechanisms from 10 River Basins, Ecology and Society, 12, 1-19. 
23. Muro M. and Jeffrey P., 2008 - A critical review of the theory and application of social learning in participatory natural resources management, Journal of Environmental Planning and Management, 51, 3, 25-344.

24. National Integrated Coastal Environmental Management Strategy (NICEMS) 2003 - Dar es Salaam: TCMP.

25. National Environmental Education and Communication Strategy (NEECS), 2005-2009 - Dar es Salaam: Rihal's General Supplies.

26. Pahl-Wostil C., Craps M., Dewulf A., Mostert E., Tabara D. and Taillieu T., 2007 - Social learning and Water Resources Management, Ecology and Society, 12, 2-5.

27. Reed M. S., Fraser E. D. G. and Dougil A. J., 2006 - An adaptative learning process for developing and applying sustainability indicators with local people, Ecological Economics, 59, 406-418, www.elsevier.com/locate/ecolecon (Accessed: 29/06/2011)

28. Reed M. S., Evely C. A., Cundill G., Fazey I., Glass J. Laing A., Newig J., Parrish B., Prell C., Raymond C. and Stringer L. C., 2010 - What is Social Learning?, Ecology and Society, 15, 4.

29. Reid W. V., Berkes F., Wilbanks T. J. and Capistrano D. (eds)., 2006 - Scales and Knowledge Systems. Concepts and Applications in Ecosystem Management, Washington, Island Press.

30. Rydin Y., Homan N. and Wolff E., 2003 - Local Sustainability Indicators, The International Journal of Justice and Sustainability, 8, 581-589.

31. Scheltinga D. M., Counihan R., Moss A., Cox M. and Bennet J. 2004 - User's Guide to Estuarine, Coastal and Marine Indicators for Regional Natural Resource Management. Cooperative Research Centre for Coastal Zone, Estuary and Waterway Management, 4-183.

32. Songorwa A. N., 1999 - Community-based wildlife management (CWM) in Tanzania. Are the communities interested?, World Development, 27, 12, 2061-2079.

33. Tanzania Coastal Management Partnership - TCMP, 1998 - An approach for linking Science to Integrated Coastal Management, Proceedings of the Scientific meeting on marine and coastal ecosystem risk assessment, Zanzibar, TCMP and IMS (in Tanzania).

34. United Nations Conference on Environment and Development (UNCED), 1992.

35. Vershuren P. and Doorewaard H., 1999 - Designing a Research Project, Utrecht, LEMMA (in the Netherlands).

36. Wagner G. M., 2005 - Participatory Monitoring of Changes in coastal and marine biodiversity, Indian Journal of Marine Sciences, 34, 1, 136-146.

37. Wagner G. M., Mgaya Y. D., Akwilapo F. D., Ngowo R. G., Sekadende B. C., Allen A., Zollet E. A. and Mackentley N., 2001 - Dar es salaam: University of Dar es Salaam.

38. Wilkinson D. (ed.)., 2000 - The researcher's toolkit, The complete guide to practitioner research, London, Routledge Farmer.

39. Yin R. K., 2003 - Case Study Research Design and Methods, 3rd Ed. London, Sage. 